\title{
INFORMATION AND COMMUNICATION TECHNOLOGY TRAINING IN FULFILLING INCLUSIVE EDUCATION AS THE ACHIEVEMENT OF SUSTAINABLE DEVELOPMENT GOALS (SDGS) POINTS 4
}

\author{
Samsinar Samsinar ${ }^{1 *}$, Denada Faraswacyen L. Gaol ${ }^{1}$ \\ ${ }^{1}$ Budi Luhur University \\ *samsinar@budiluhur.ac.id
}

\begin{abstract}
The Sustainable Development Goals (SDGs) covers 17 goals with 169 measurable achievements and deadlines determined by the United Nations in 2015 as the world development agenda for the benefits of human beings and the Earth. The joint development ambition is set to be done in 2030. For the community service discussed in this article, the team focuses on the $4^{\text {th }}$ goal, namely quality education. The goal ensures the quality of inclusive and equitable education, and promotes a lifetime learning opportunities for all. The practical objectives of such education include direct goals by children, teachers, parents, and the community. Such education means providing equal and fair opportunities for all disregarding their backgrounds, circumstances, economic abilities, etc., which are considered as obstacles to obtain education. The development of Information Communication Technology (ICT) has touched many fields in everyday life and is no exception for persons with disabilities. For persons with disabilities, ICT devices are widely used to support and ease the process of completing tasks and encourage creativity. The ICT training for educators and caregivers is an educational process aiming to provide sufficient understanding on the use of ICT device systems as supporting systems for completing daily tasks thus increasing productivity.
\end{abstract}

Keywords: ICT, Inclusive Education, Quality Education, SDGs

\section{INTRODUCTION}

Sustainable Development Goals or SDGs are 17 goals with 169 measurable achievements and deadlines that have been determined by the United Nations as the world development agenda for the benefit of humans and planet earth. This goal was jointly proclaimed by intergovernmental countries in the UN resolution published on October 21, 2015 as ambition for joint development until 2030. This objective is a continuation or replacement of the Millennium Development Goals (MDGs) signed by leaders from 189 countries as The Millennium Declaration at UN headquarters in 2000 and is no longer valid since the end of 2015.

SDGs was formulated since July 19, 2014 and submitted to the United Nations by the Open Working Group of the SDGs. In the proposal there are 17 objectives with 169 achievements covering sustainable development issues including eradication of poverty and hunger, improvement of health, and education, development of a more sustainable city, addressing climate change, and protecting forests and the sea. In August 2015, 193 countries agreed to the following 17 goals:

1. No Poverty

2. Zero Hunger

3. Good Health and Well Being

4. Quality Education
End poverty in all its forms everywhere

End hunger, achieve food security and improved nutrition and promote sustainable agriculture

Ensure healthy lives and promote well-being for all at all ages

Ensure inclusive and equitable quality education and promote lifelong learning opportunities for all 
5. Gender Equality

6. Clean Water and Sanitation

7. Affordable and Clean Energy

8. Decent Work and Economic Growth

9. Industry, Innovation and Infrastructure

10. Reduced Inequality

11. Sustainable Cities and Communities

12. Responsible Consumption and Production

13. Climate Action

14. Life Below Water

15. Life On Land

16. Peace and Justice Strong Institutions

17. Partnerships to Achieve the Goal
Achieve gender equality and empower all women and girls

Ensure availability and sustainable management of water and sanitation for all

Ensure access to affordable, reliable, sustainable and modern energy for all

Promote sustained, inclusive and sustainable economic growth, full and productive employment and decent work for all

Build resilient infrastructure, promote inclusive and sustainable industrialization and foster innovation

Reduce inequality within and among countries

Make cities and human settlements inclusive, safe, resilient and sustainable

Ensure sustainable consumption and production patterns

Take urgent action to combat climate change and its impacts

Conserve and sustainably use the oceans, seas and marine resources for sustainable development

Protect, restore and promote sustainable use of terrestrial ecosystems, sustainably manage forests, combat desertification, and halt and reverse land degradation and halt biodiversity loss

Promote peaceful and inclusive societies for sustainable development, provide access to justice for all and build effective, accountable and inclusive institutions at all levels

Strengthen the means of implementation and revitalize the global partnership for sustainable development

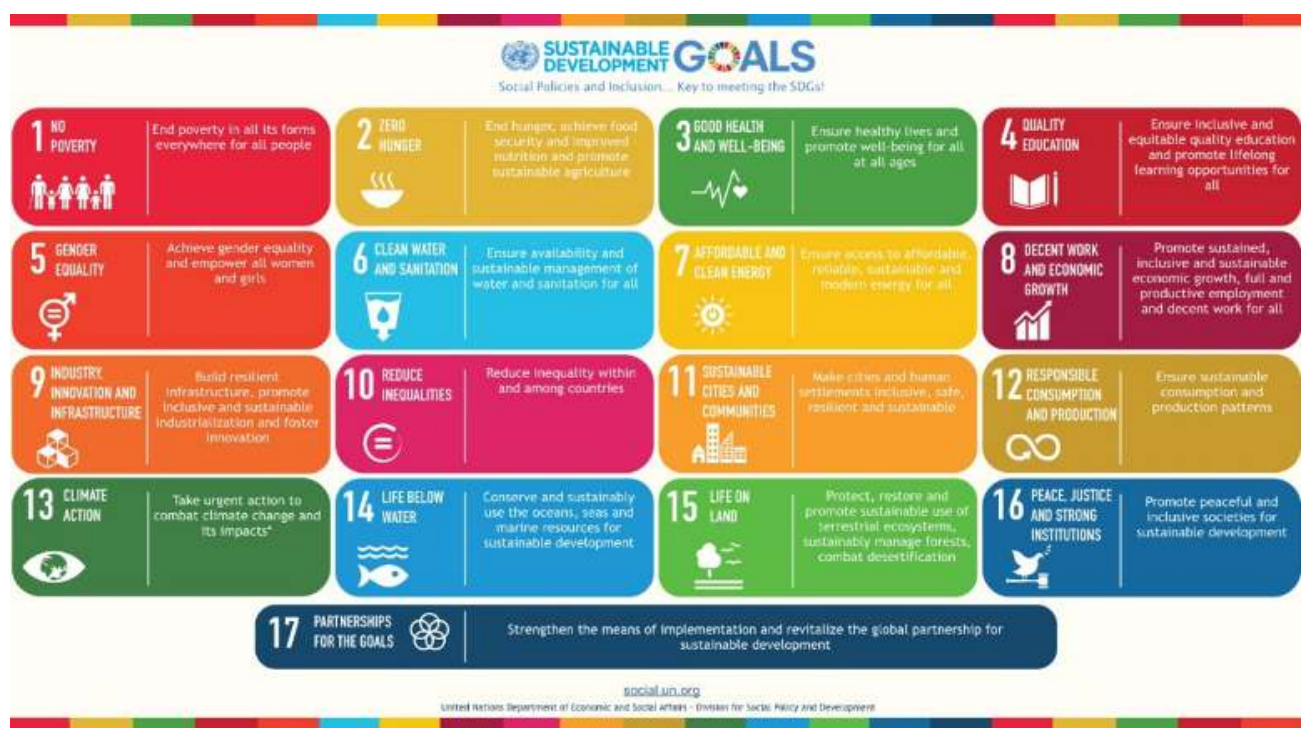

Figure 1. The 17 Sustainable Development Goals (SDGs) 
From the description of the seventeen goals, the focus of activities in the implementation of Community Service (PKM) in the Semester of Academic Year 2016/2017 is the fourth goal, namely quality education. SDGs Point 4 ensures the quality of inclusive and equitable education and promotes lifetime learning opportunities for all. In general, education is a conscious and planned effort to realize the learning atmosphere and learning process so that students actively develop their personal potential to have religious spiritual strength, self-control, personality, intelligence, noble character, and skills needed by themselves, society, nation, and State (Indonesian Law, Act. No. 20 of 2003, Article 1 paragraph 1). Therefore, the essence of inclusive education is human rights to education. A logical consequence of this rights is that all children have the rights to receive education by not discriminating people based on disability, ethnicity, religion, language, gender, ability and others. The practical objectives to be achieved in inclusive education include direct goals by children, by teachers, by parents and by the community.

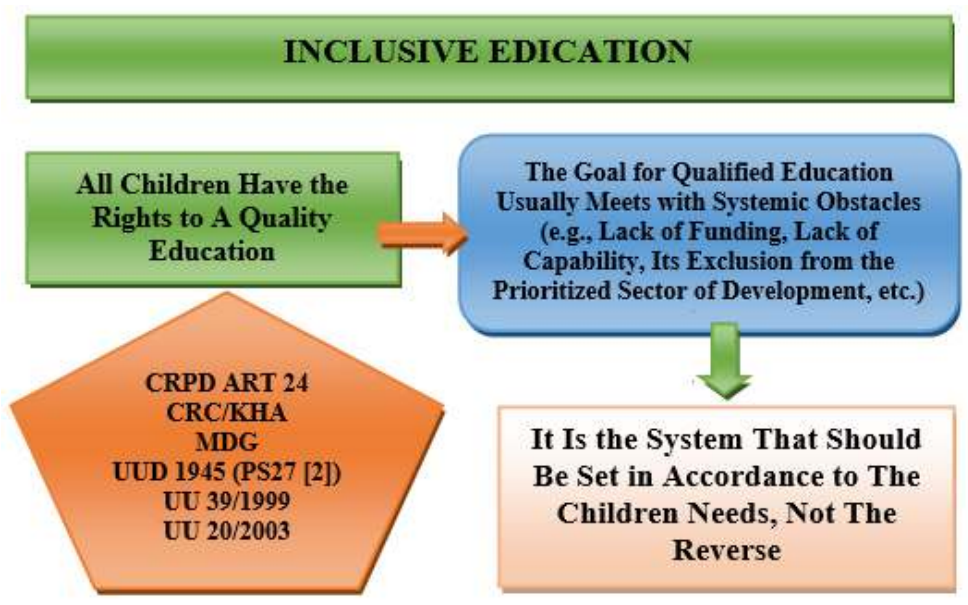

Figure 2. Inclusive Education

Referring to SDGs Point 4, children with disabilities or who have physical limitations also have the rights to get education like other normal children at their age. The quality of inclusive and equitable education means providing equal and fair opportunities for all disregarding their background, circumstances, economic abilities, etc., which are considered as obstacles to obtaining education. Children are the future generation of future leaders who must be equipped with knowledge to be able to be independent and compete in the midst of their limitations.

People with disabilities face more challenges in life than the other normal people. People with disabilities sometimes lack of attention, and are often underestimated, even though they also need knowledge, affection, and attention from many people. They are actually smart, confident, and creative children. They can be helped through formal method. The blind can be taught Braille so they can read properly and correctly. Those who cannot hear are given hearing aids so that they understand what the people around them are saying. Therefore, there is no excuse to let them become people who do not know anything. For those who cannot see are given sticks so that they can lead them to the place they are walking, do not let them walk alone without the slightest help that can cause them harm. If there are people with disabilities who are able to attend inclusive schools, give them the opportunity. They can also be given the opportunity to show their strengths, instead of alienating them. For those who care can help each other so that they could foster independency, self-confidence, and creativity so that they could have a bright future, achieve the ideals they dreamed of since they were young, and fight for their rights.

Based on the Convention on the Rights of Persons with Disabilities, Article 21, concerning the freedom of expression and opinion, and access to information, States parties must take all appropriate policies to ensure that persons with disabilities can use the rights to freedom of expression and opinion, including freedom to seek, receive, and provide information and ideas, on an equal basis with others, 
and through all forms of communication of their choice. As stated in Article 2 of this Convention, such responsibility includes:

a) Provide information aimed at the general public to persons with disabilities in the form and technology that can be reached in accordance with various types of disabilities in a timely manner and without additional costs;

b) Accept and facilitate the use of sign language, Braille, augmentative and alternative communication, and all means, tools and other forms of communication that can be reached in accordance with the choice of persons with disabilities in official interactions;

c) Call for private entities that provide services to the general public, including through the internet, to provide information and services in a form that can be reached and used by persons with disabilities;

d) Encourage mass media, including information providers through the internet, to make their services accessible to persons with disabilities;

e) Recognize and promote the use of sign language.

Forms of learning that can be given to children with disabilities can be modified using modern technology tools. The development of Information Communication Technology (ICT) has touched many fields in everyday life and is no exception for persons with disabilities. The tools and equipment for daily activities related to ICT devices are widely used to support and ease the performance of tasks completion and encourage the birth of their creativity as persons with disabilities. Yayasan Sayap Ibu is a social institution that cared for and cared for children with multiple disabilities. In carrying out their daily activities, the teaching staff and caregivers at Yayasan Sayap Ibu need a lot of help and support from various parties including in increasing the knowledge and expertise of the teaching staff and caregivers. Roles, duties, and responsibilities carried out in carrying out their social functions to educate and take care of the young children do not only require hard skills but also soft skills.

Based on intensive communication carried out by the Budi Luhur University PKM Team with Yayasan Sayap Ibu Cab. Bintaro, it is agreed that the form of training required by educators and caregivers is Document Management Techniques and making correspondence using Microsoft Office Word. The submission of this training material based on their level of knowledge and ability in Document Management and making correspondence using Microsoft Office Word is still very limited so that the PKM Team involves the member from the Faculty of Social and Political Sciences, and from the Faculty of Information Technology in accordance with their respective scientific competencies. Technical Techniques in Managing Documents and correspondence using Microsoft Office Word are then used to support task in managing documents and making correspondence well systematically.

Based on the description, the PKM team plans to conduct IT training activities in the field of document management and correspondence using Microsoft Office Word for educators and caregivers at the Yayasan Sayap Ibu (YSI) Banten Province Branch on December 3 and 4, 2016. PKM Team executives consist of an International Relations lecturer and Information System lecturer, related to the SDGs agenda and the use of ICT. The foundation nurtures and educates physically disabled children to be smarter, more creative, and more independent in their daily activities.

\section{METHOD}

The methods used in the implementation of this activity are:

1. Observation

The Implementation Team of Community Service (PKM) Universitas Budi Luhur made observations to the Yayasan Sayap Ibu Banten Province Branch to find out the conditions of children with disabilities and caregivers. Observations were made in several visits, by observing learning activities inside and outside the classroom, as well as the activities of children with disabilities living in dormitories.

2. Interview

The PKM Team held meetings and interviews with the Head of Yayasan Sayap Ibu Banten Province Branch and several caregivers or mentors. Then, the foundation submitted an Application Letter to the PKM Team to carry out activities according to the agreed theme. Afterwards, the PKM Team made coordination with the school in relation to the schedule and activity material.

3. Interaction / communication 
Interaction with several caregivers of children with disabilities was done by verbal communication through the team coordinator.

\section{RESULT AND DISCUSSION}

The results of the implementation of community service activities at the Banten Province branch of the Yayasan Sayap Ibu are:

1. Preparation Stage

The preparation stage is carried out to plan all the needs that will be used during the implementation of the activity. This stage consists of:

a) Preparation of Team Members and Tasks Allocation

The implementation team consists of: Denada Faraswacyen L. Gaol, M.Si. from Faculty of Social Science and Political Science as the team coordinator; Samsinar, M. Kom. From Faculty of Information Technology as the trainer or instructor. Two students namely Hilastu Firdhaus and Richiqo Fajar Rahman assisted this PKM. The students were assigned to accompany the training participants, which are the caregivers at the Yayasan Sayap Ibu, Bintaro.

b) Correspondence and communication with management and caregivers at the Yayasan Sayap Ibu, Bintaro.

Communication with the Yayasan Sayap Ibu Bintaro in the process this was helped by the submission of a Request Letter from the Companion student Hilastu Firdhaus, addressed to the PKM Organizing Committee to follow up communication by the Chairperson of PKM Mrs. Denada Faraswacyen L. Gaol, M.Si with Mrs. Rini representative from Sayap Ibu Foundation, Bintaro. Based on correspondence and communication carried out, the agreement on the implementation of PKM activities on February 6 and 7, 2017 is regulated.

c) Preparation of Props (Persiapan Alat Peraga)

The PKM team prepares equipments needed for the training consisting of: Notebook, LCD Projector, cable roll extension, banners, and cameras for documentation purposes. The team coordinator made coordination with Ibu Rini from Yayasan Sayap Ibu in preparing the number of trainees, rooms, and supporting facilities related to the activities.

2. Implementation Phase

On Monday, 6 February 2017 at 08:00 WIB PKM Team departed from Universitas Budi Luhur to Yayasan Sayap Ibu Bintaro to carry out the community service activities at 09:00 WIB. The PKM Team consists of Faculty of Social Science and Political Science and FTI lecturers and several Faculty of Social Science and Political Science students. The training is conducted by Ms. Samsinar, M.Kom, who explained about the use of Microsoft office to improve the understanding of educators and caregivers at Yayasan Sayap Ibu Bintaro. Yayasan Sayap Ibu Bintaro who wants to increase their insight and understanding in office administration activities requested the Microsoft office material. The participants seemed enthusiastic in receiving the explanation from the trainer. This can also be seen from the dialogue, which was proactive from both the trainer and from the trainees. 


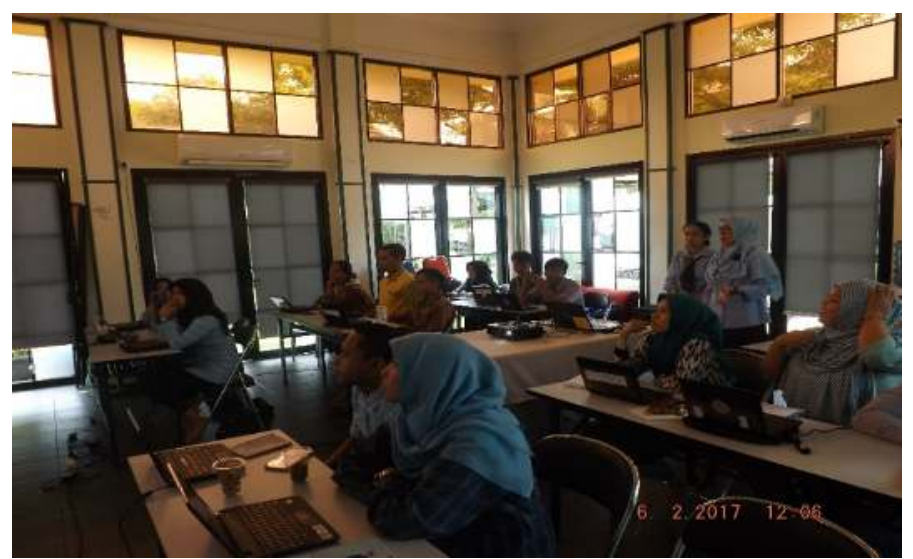

Figure 3. Training Participants Listened to the Explanation from the Instructor

Training participants responded by asking a number of questions related to their daily tasks and work at the Yayasan Sayap Ibu Bintaro office. Training materials are tailored to the needs of their office routines so that they can be applied directly in work activities. The explanation of the material was divided into several sessions interspersed with discussions between participants and team members.

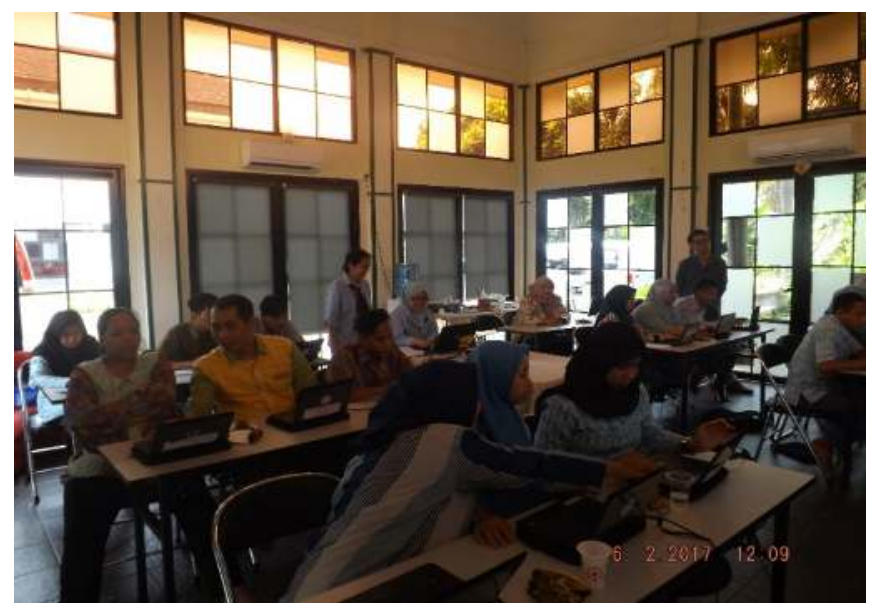

Figure 4. Team Members Assist Training Participants in Doing Task Exercises from Speakers

After the speaker gave an explanation in several scheduled sessions, the participants were given practice questions to measure their level of understanding regarding the material that had been delivered. The method of working out the practice questions is carried out for individual and in group so that the achievements of each participant can be assessed. The participants could as well help one to another.

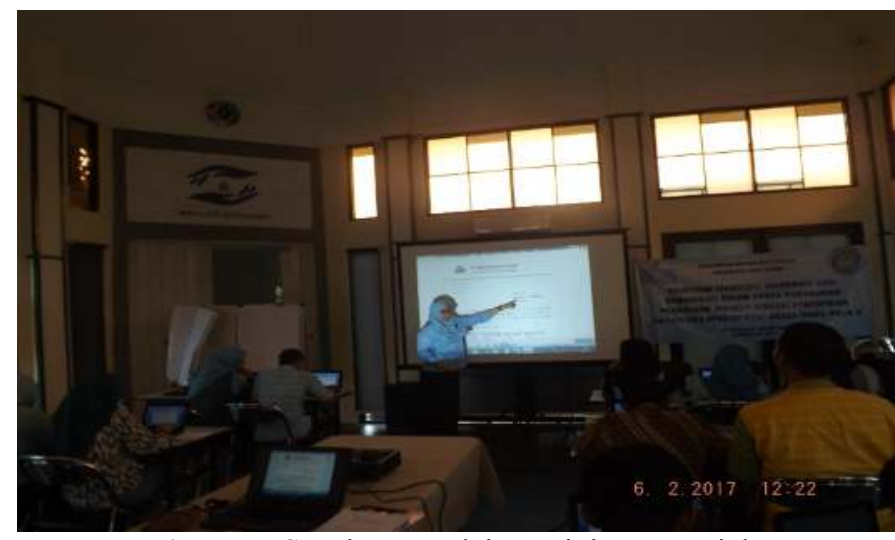

Figure 5. Speakers Explain Training Materials 
The training was warmly welcomed by the trainees and it was hoped that there would be a continuation of similar activities as a form of deepening the understanding on several computer systems that they did not understand because the progress of computer used as the support for their office activities has not been maximized considering the limitations and difficulties in getting trainers or instructors in provide training to teachers and caregivers at the Yayasan Sayap Ibu Bintaro.

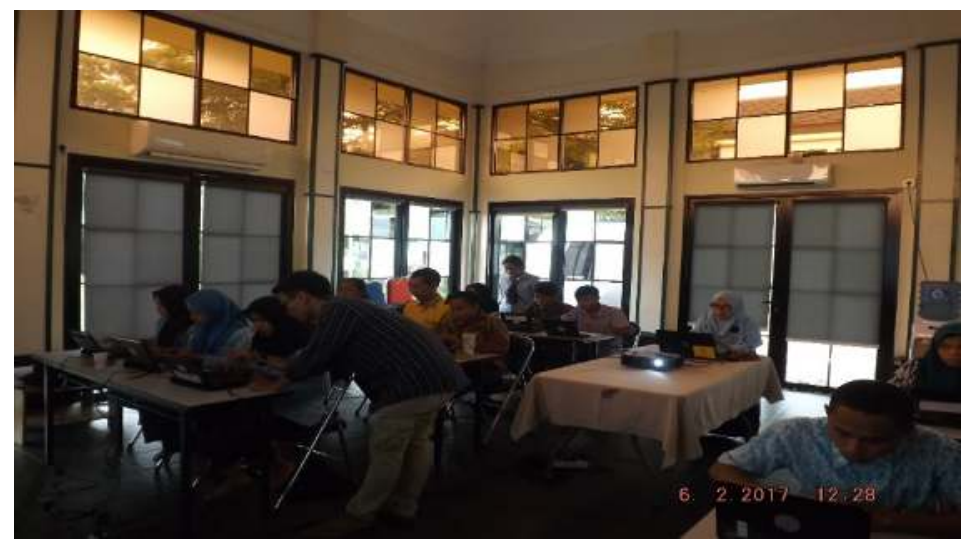

Figure 6. Companion Student Provides Additional Explanations

This PKM activity involves several accompanying students as additional trainers who help the instructor in providing additional explanations to each trainee who found difficulty or did not understand the material provided. This is done so that the target of the PKM implementation is achieved, which is to give an explanation according to the material needed and mentor them one by one, until the participants understand and can apply their knowledge in office activities.

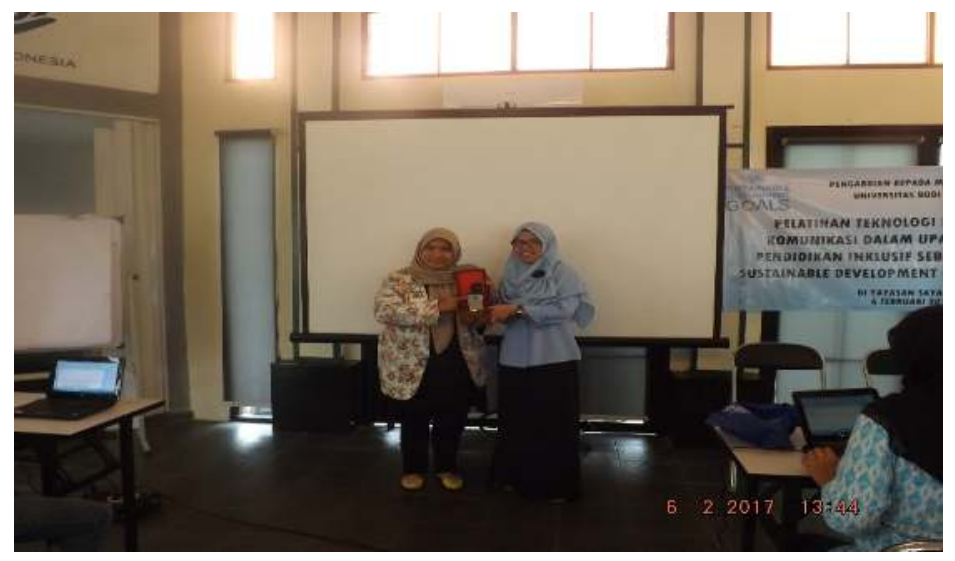

Figure 7. The Instructor Gives Universitas Budi Luhur Plaque to the Representative of Yayasan Sayap Ibu

The training was completed in the afternoon followed by the giving of Universitas Budi Luhur plaque as a souvenir to Yayasan Sayap Ibu and ended with a lunch attended by the PKM Team and the trainees. 


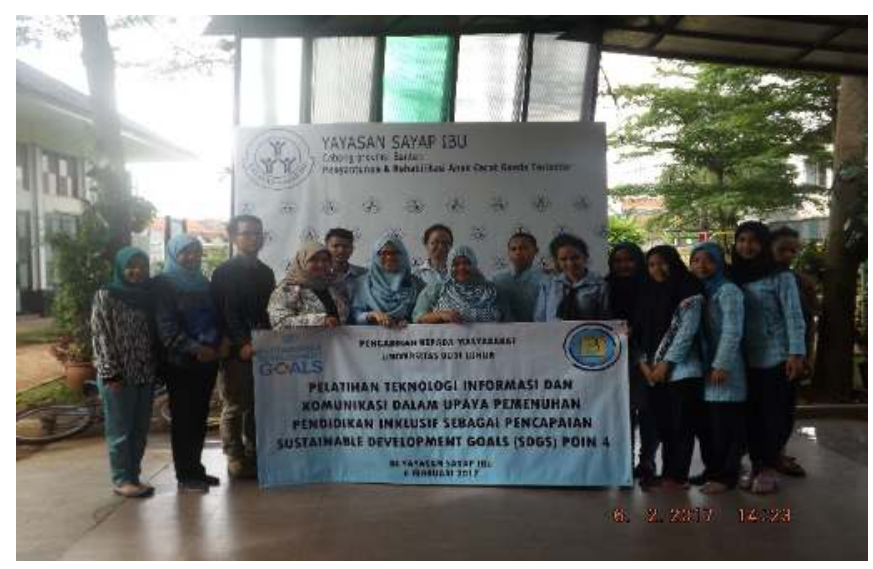

Figure 8. Universitas Budi Luhur PKM Team and the Representative of Yayasan Sayap Ibu At the final session of the training program, the PKM Team and information technology and communication-training participants took a picture together.

\section{CONCLUSION}

In supporting and implementing Sutainable Development Goals (SDGS) Point 4, namely quality education as one of the global agendas, which is a study of the International Relations Study Program of Faculty of Social Science and Political Science, the Faculty of Social Science and Political Science Community Service (PKM) Team of Universitas Budi Luhur conducted information and communication technology training to educators and caregivers at the Yayasan Sayap Ibu, Bintaro. PKM activities are one of the Tridharma (three obligations) for college lecturers, which is implemented by providing knowledge and insight to the people in need.

Activities carried out at Yayasan Sayap Ibu are a form of support for educators and caregivers in sharing the knowledge they need in carrying out daily activities in the office, especially those related to the use of ICT devices in performing their work. The community service involved several Faculty of Social Science and Political Science and Faculty of Information Technology lecturers as well as students as instructors and facilitators. The activity was carried out in two days and attended by twenty very enthusiastic participants, marked by many positive responses during the training process, stating that the training was very useful for them. The participants also hoped that there would be a continuation of the same training for the next semester.

\section{REFERENCES}

www.undp.org/content/undp/en/home/sustainable-development-goals.html diakses pada 1 November 2016 pukul 09.00 WIB.

Undang-Undang Republik Indonesia Nomor 19 Tahun 2011 tentang Pengesahan Convention on the Rights of Persons with Disabilities (Konvensi Mengenai Hak-Hak Penyandang Disabilitas)

http://yayasansayapibu.or.id/cabang/banten/ diakses pada 2 November 2016 pukul 09.00 WIB.

http://sayapibujakarta.org/ diakses pada 14 September 2018 pukul 10.00 WIB.

Buklet Panduan Pelaksanaan PKM Universitas Budi Luhur 2016 